\title{
DEVELOPMENT OF BEEF RAISING PRODUCT MANUFACTURING ON THE INNOVATIVE BASIS
}

\author{
Oleksandr Nakai \\ Bukovinian University, Faculty of Economics, Department of Accounting and Auditing, \\ Chernivtsi, Ukraine
}

\section{(C) MESTE NGO}

JEL category: D2, 014, 03, Q19

\begin{abstract}
In terms of agricultural sector, reformation of beef production is necessary, in order to reduce livestock output and the concentration of production. In accordance with this, in the period between 1990 and 2010, cattle production in all parts of the Chernivtsi region decreased by 331.7 thousand units, or $74.0 \%$. The main reason for this negative trend is the unprofitable beef production, which is primarily due to the low animals' productiveness, net realizable value of live weight and its high cost. In order to solve the strategic tasks of beef breeding it is necessary to support the innovative activities of scientific and technological progress and innovative organizational economic reforms in agriculture. The priorities concerning innovative processes in this field are connected with the improvement of cattle's quality and species composition, production of food and feeding systems for the cattle, the usage of power-saving technologies that take into account beef raising reproduction peculiarities and make it possible to improve efficiency and competitiveness of agricultural field.
\end{abstract}

Keywords: innovation processes, efficiency in production, beef raising products, animals productiveness, manufacturing costs, realizable value.

\section{INTRODUCTION}

Livestock rising is an important sector of agriculture, which occupies a significant portion in the structure of its gross output. Development of innovation processes in livestock raising is

The address of the author:

Oleksandr Nakai

奉=" Nakay84@mail.ru connected with the resource potential on a qualitatively new basis. Accordingly, the competitiveness of the industry is largely determined by the use of science and technology at all stages: from research to the development of their results in practice. (Putsenteilo, 2012)

From 1009 agricultural enterprises in Chernivtsi region 235 enterprises (23.3\%) are involved into the development of livestock rising. In 2010 costs of beef raising products of the regional farms 
amounted to 340.1 million, or $40.3 \%$ of all manufacturers' production costs. The production of meat in slaughter weight of all categories of agricultural enterprises in Chernivtsi region in the structure of the regions in Ukraine took: $1990-$ $1.8 \%, 1995-2.1 \%, 2000-1.8 \%$, in $2005-$ $1.9 \%, 2010-1.9 \%$.

Due to the deteriorating situation in this meat industry the Ministry of Agriculture together with scientists drafted an innovative investment model of livestock development. It has to provide financial investment support for the implementation of new productive technologies into the growing of young cattle, pigs and poultry, tested by European and international practice, and the development of selection and breeding work. (Petryshyn, 2008)

One of the major livestock raising industries in Ukraine's agriculture is cattle breeding, which figures prominently in addressing state food security because it provides citizens with such valuable foods as milk and beef. It should be noted that cattle breeding is a kind of "engine" of the livestock raising industry, which consumes significant amounts of crop production.

Separate specialized industry is beef cattle breeding, the main task of which is to produce high quality beef and tough leather on the basis of breeding meat cattle breeds. (Cherkaschenko, 1975) In particular, a beef cattle breeding is a supplier of raw materials for the development of light industry, organic fertilizer. Beef is the most valuable kind of meat nutritionally and for taste, in comparison with pork and lamb it has less fat. Fat and protein in beef are in the most favorable ratio, and the even distribution of fat provides meat with "marbling". The main advantage of this industry is that cattle can most effectively use coarse and succulent food with much less consumption of expensive concentrated foodstuff.

Natural and climatic conditions of Chernivtsi region, which is divided into steppe, foothills and mountain areas, promote the development of livestock, particularly beef. Primarily this is due to large areas of natural grasslands. Therefore, region requires new approaches to the strategy of livestock industry, the search for effective ways of producing cheap, high-quality and costeffective beef and milk. (Kalynka, 2010)

For the beef raising development an advanced science-based resource-saving technology of beef raising cattle was introduced on the basis of Bukovinian Institute APV biochemistry. In the region plant breeding and five reproducers of Ukrainian Simmental beef breeding are functioning. Bukovinian type of this breed features adaptability to farming in the foothills of the and pastures reaches $39.3-54.8 \%$ and pasture period is $220-270$ days. This is a guarantee of efficient resource-saving pasture beef raising development. (Vyhrystiuk, 2006)

\section{ANALYSIS}

In the terms of the agricultural sector reforming beef rising is inherent in tendency to reduce livestock output and reduce the concentration of production. Thus, during 1990-2010 cattle in all categories of the region decreased by 331.7 thousand units, or $74.0 \%$, including agricultural enterprises to 309.8 thousand units, or to $95.4 \%$ (fig. 1).

There is also a reduction of livestock in the people's households, so during the 1990-2010 cattle decreased by 21.9 thousand units, or $17.7 \%$. Such tendency affects the total output of beef cattle as biological features and low rates of updating do not allow restoring livestock herds quickly.

In recent years, despite attempts to reform agriculture, a decline in the production of beef and veal is observed (fig. 2).

At the same time the level of livestock productiveness remains low and does not fully compensate the reduction in the number of cattle. Despite the increase in average daily gain of cattle over the past few years, beef production in the Chernivtsi region remains very low, and more than 2 times less than in the U.S., Canada and Western Europe, where this figure is an average of 1000-1200 units. Meat and meat products are important building blocks of product consumption basket. As one of the essential food meat is available for consumption in raw form or in the form of processed products. 


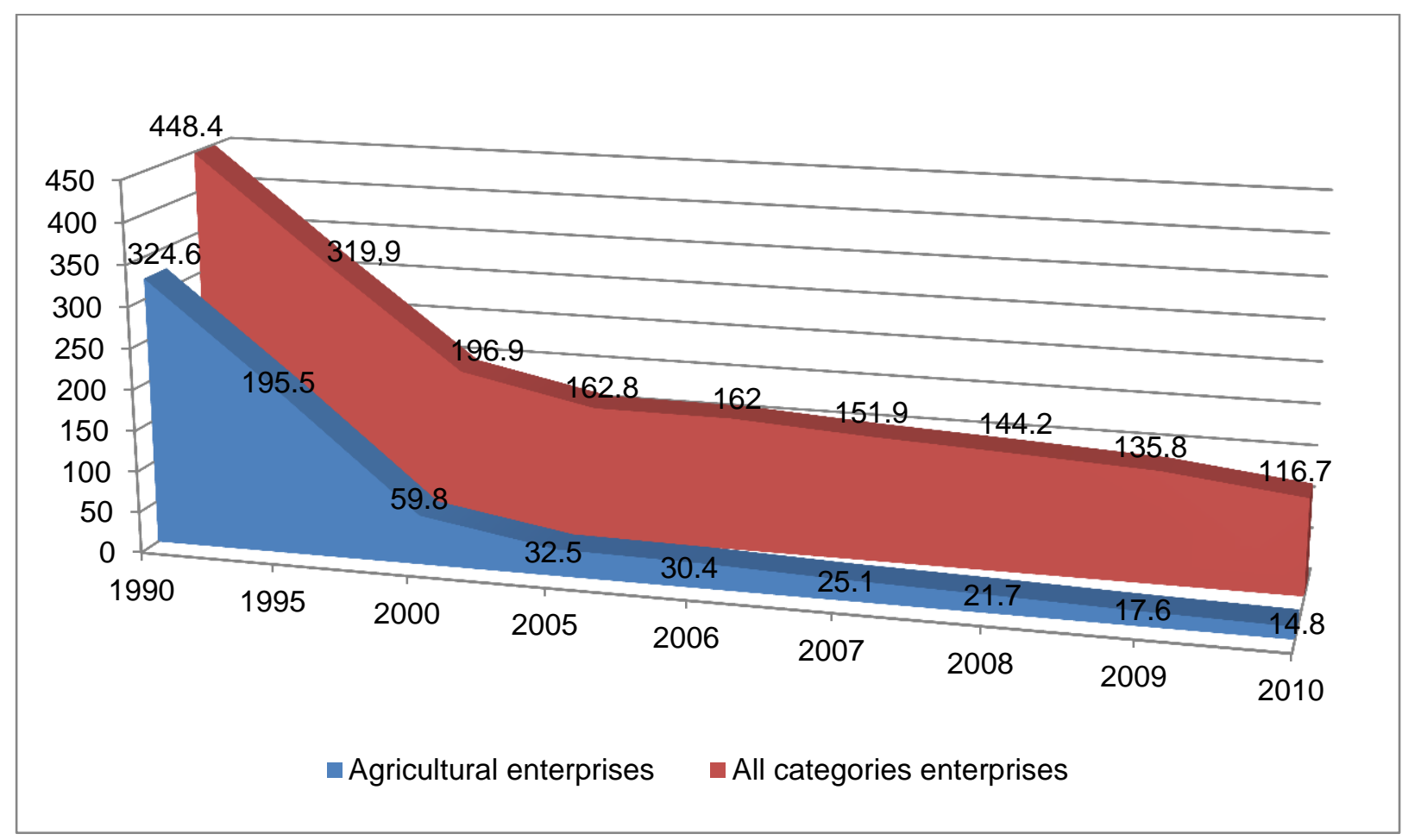

Figure 1 Dynamics of cattle livestock in the Chernivtsi region

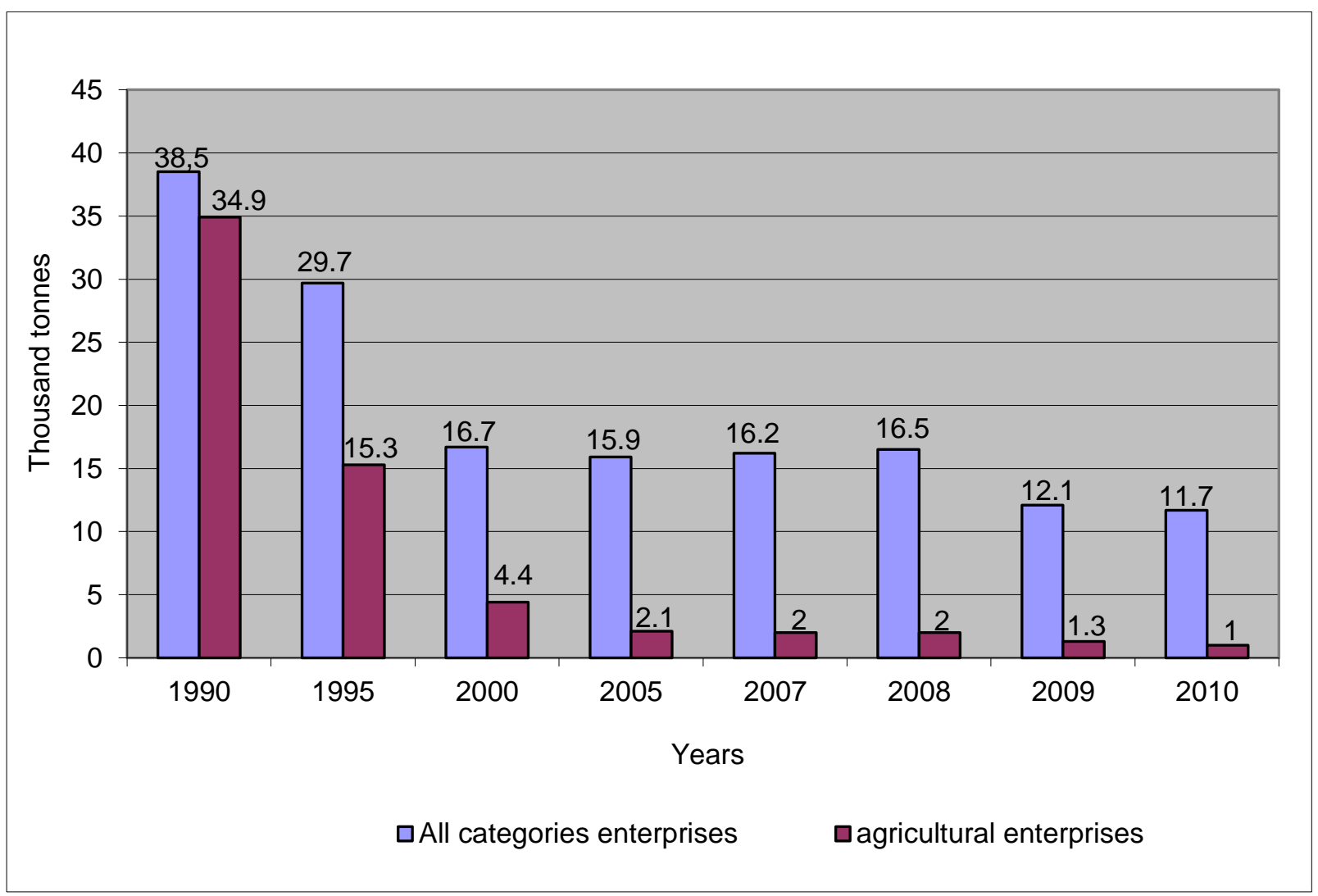

Figure 2 Dynamics of production of cattle meat (slaughter weight) in the Chernivtsi region 
Significant reduction of the consumption of some important types of food by the country's population and changing of dietary pattern is an important indicator of reduction of the quality of life. During the studied period of time dangerous for its social and demographic consequences reduction of average food consumption, especially of animal products can be observed.

Consumption of meat and meat products per capita in the region during $1990-2010$ decreased from $52.4 \mathrm{~kg}$ to $42.8 \mathrm{~kg}$ and is $51.6 \%$ of the science-based standards of consumption $83 \mathrm{~kg}$ per 1 person. In particular, the consumption of beef and veal was $9.8 \mathrm{~kg}$, which is in $50.3 \%$ less than the physiological minimum and in 3.7 times less according to the sciencebased standards.
These figures show the urgent need for increased consumption of meat. Meat of farm animals is rich in complete protein containing essential amino acids, minerals, vitamins and almost completely absorbed by the human body. (Prysiazhniuk, 2011)

Consider the efficiency of production of beef cattle farms in the Chernivtsi region (table 1). In the dynamics of years there was a significant decrease in the gross production of beef cattle to 23.5 times, increase in body weight of cattle on 100 hectares of agricultural land decreased in 7.0 times. Also, a decrease in average daily live weight gain per head of cattle for $24 \mathrm{~d}$, or $4.9 \%$. Feed costs per $1 \mathrm{~kg}$ gain increased by $1.86 \mathrm{~kg}$ feed units, or $15.1 \%$.

Table 1 Dynamics of production efficiency of the meat of cattle in the agricultural enterprises of Chernivtsi region

\begin{tabular}{|c|c|c|c|c|c|c|c|c|}
\hline \multirow{2}{*}{ Indices } & \multicolumn{7}{|c|}{ Years } & \multirow{2}{*}{$\begin{array}{l}2010 \text { to } \\
1990 \%\end{array}$} \\
\hline & 1990 & 2000 & 2005 & 2007 & 2008 & 2009 & 2010 & \\
\hline $\begin{array}{l}\text { Gross production, } \\
\text { thousands of UAH }\end{array}$ & 305767 & 34565 & 25924 & 20274 & 19143 & 16086 & 13028 & 4.3 \\
\hline $\begin{array}{l}\text { Increase in body weight of } \\
100 \text { hectares of agricultural } \\
\text { land, Cwt }\end{array}$ & 131.7 & 17.9 & 24.2 & 28.3 & 25.6 & 39.2 & 18.8 & 14.3 \\
\hline $\begin{array}{l}\text { Average daily live weight } \\
\text { increase per head, } h\end{array}$ & 492 & 264 & 451 & 424 & 464 & 453 & 468 & 95.1 \\
\hline $\begin{array}{l}\text { Feed expenses per } 1 \mathrm{Cwt} \\
\text { increase, Cwt feed units }\end{array}$ & 12.33 & 14.98 & 14.57 & 14.39 & 13.77 & 16.37 & 14.19 & 115.1 \\
\hline $\begin{array}{l}\text { Manufacturing costs of } \\
1 \text { Cwt of live weight sold, } \\
\text { UAH }\end{array}$ & - & 542.87 & 692.06 & 913.53 & 1111.41 & 937.8 & 1308.27 & $\begin{array}{l}\text { in } 2.4 \\
\text { times }\end{array}$ \\
\hline $\begin{array}{l}\text { Realizable value of } 1 \text { Cwt of } \\
\text { live weight, UAH }\end{array}$ & - & 201.71 & 591.88 & 514.79 & 800.99 & 754.3 & 870.31 & $\begin{array}{l}\text { in } 4.3 \\
\text { times }\end{array}$ \\
\hline Profitability (loss), \% & 27.1 & -38.3 & -9.3 & -33.3 & -18.5 & -29.7 & -33.5 & $-60.6 \mathrm{pp}$ \\
\hline
\end{tabular}

In $2000-2010$ the manufacturing costs of $1 \mathrm{~kg}$ of live weight sold of cattle increased by 2.4 times, and the selling price increased to 4.3 times. However, despite the accelerated growth rates, significant dominance of manufacturing costs over the price contributed to unprofitable activity of agricultural enterprises in the region. The high cost of meat production is offset by proceeds from its sale. As a result of this situation, the more meat is produced by the farm, the more losses it gets. The same was true for most farms of Chernivtsi region.

One of the major causes of reduced economic efficiency of production of beef cattle is unreasonably high prices for energy and combined foodstuff. In particular, at certain times this industry has not received budgetary subsidies. In 2010 most state funds to support farmers in Chernivtsi region aimed at pork production $-4,411.7$ thousands, or $61.6 \%$, to 
produce beef $-2,019.7$ thousands, or $2.2 \%$ and 727.9 thousands, or $10.2 \%$ devoted to support all kinds of poultry. Presently it's appropriate to direct most funds to support cattle-breeding, as this would encourage companies to increase meat breeds of cattle.

Today beef rising in Ukraine is not a prosperous industry. There are a few agricultural enterprises in Ukraine that are engaged in cattle breeding of meat and dual-purpose breeds. The greater part of enterprises is mostly specializing in the development of dairy farming.

However, the beef raising industry has a number of advantages comparing with other fields:

1) beef raising is a low-cost industry, since it requires less power consumption, heat, labor, equipment, comparing with the dairy industry;

2) in each area there are empty houses, which can be used for fattening cattle breeds after a relatively inexpensive repair;

3) the development of the beef raising industry gives an opportunity to make full use of natural pastures;

4) enterprises can get a big beef yield from cattle;

5) beef is always in demand, since it is a source of protein of animal origin.

It should be noted that the level of state support is a key factor in ensuring the competitiveness of beef cattle. The experience of countries with developed and efficient agriculture shows that intensive industry development is impossible without government regulation, based on systematic and long-term approach. In fact, in many countries of the world just the financial support from the state ensures the necessary level of profitability for agricultural producers. (Dunin, 2011)

In beef rising, as well as in other agricultural fields, there is a number of objective factors, the impact of which cannot be eliminated through organizational transformation. In particular, low capital turnover, technological continuity, unpredictable climatic conditions are included. Therefore, the objective existence and manifestation of the influence of these factors lead to the need of government support - grants, concessional lending.

The development of innovational activities in beef rising will largely depend from the degree of budgetary support. Taking into consideration the specifics of the given industry, the main commercial products will begin to flow only in 3 4 years after the initial formation of beef herd. Consequently, beef rising will require the government assistance the most during this period.

For further improvement of the economic efficiency of beef production it is necessary to provide an innovative part of the production process. Innovative technology is a strategic factor for the economic stability of the meat industry, while effective production allows the implementation of advanced technology, ensuring high profitability of production.

Today, essential to increase production potential, is the use of biological unit of innovation, achievements in the selection, which reflects the main directions to improve breeding and genetic potential, on which the level of animal productivity, efficient use of food resources, development of resource-saving technologies aimed at improving level of intensity and efficiency depends. (Mazurenko, 2012) A prerequisite for the innovation processes development in the industry is also increasing of livestock productivity while reducing manufacturing costs, especially on foodstuff. Among the factors intensifying meat sector feeding occupies a special place because foodstuff is the main source to maximize productivity.

The presence of disparity between the development of food resources and livestock leads to the realization of animals' genetic productivity potential not in full. This is due to the low quality of food resources, the lack of sciencebased food allowance, balanced according to the basic feeding elements.

During the analyzed period of time the feed costs per $1 \mathrm{~kg}$ of cattle's live weight increase grew from 12.3 to $14.2 \mathrm{~kg}$ feed units, and average daily increase in growing and fattening fell from 492 to $468 \mathrm{~g}$. That is, due to the increase of feed resources in $15.4 \%$ meat productivity decreased 
in $4.9 \%$. This is possible only in case of low quality food allowance, that do not meet the physiological needs of animals and the most part of the food recourses is used as maintenance.

In particular, the structure of diet feeding increased the proportion of concentrated feed at $2.1 \mathrm{~kg}$ feed units, or $11.7 \%$. The increase of the proportion of concentrated foodstuff is connected primarily with feeding animals with grain in nonprocessed form. Manufacturers doing business using out dated technologies include in the diet of animals not feed but grain, that greatly impacts on reducing their productivity and increases the proportion of forage in the structure of manufacturing costs.

Therefore, to increase the productivity of food allowance it is necessary to balance the food recourses according to all necessary micro- and macro feeding elements taking into account all the latest scientific developments in this field. In particular, it is important not only to increase the overall feeding costs in livestock, but to consider their qualitative characteristics. Only in this case it is possible fully realize the existing livestock productivity potential.

So innovation processes related to the improvement of feed manufacturing have a significant impact on the increase the of cattle production efficiency.

Analysis of industry's current trends in developed European countries and the United States demonstrates impossibility in achieving high productivity of livestock without purposeful selection and breeding work and picking out the best breeds in the world for reproduction. That is why Ukraine needs large-scale replacement of existing extensive animal species with the intensive animal species. In particular, for the beef raising development it is necessary to increase the share of Hereford, Charolais, Aberdeen Angus and other specialized breeds of cattle.

It is proved scientifically and in practice that only the use of the best breeds of the world gene pool adapted to the industrial production technology can provide herd's qualitative renewal and, subsequently, increase the competitiveness of domestic products in a short time. It should be noted that the application of innovative technologies determines the competitiveness of individual enterprises in the industry, is the material basis of its development and the optimal intensity and the highest economic efficiency is put down at the stage of agricultural technology design and development.

Ukrainian market conjuncture of beef raising products to some extent is determined by the imported products. A significant volume of imports restrains the innovative development of national producers. The monopoly of meat processing plants, which significantly reduced the proportion of raw material costs in retail, also contributes to such a situation. The profitability in the meat sector is significantly lower than in the whole economy. In this regard, farmers are not only unable to keep their production facilities on the basis of the latest achievements of science and technology, but also to maintain existing facilities in working order.

The development of innovative activities in livestock is correlated as well as with regional and with internal peculiarities of this sector. In various natural-economic zones and livestock sub-sectors biological processes go on unequally, which requires accounting and an individual approach in the distribution mechanisms of investment resources and products pricing formation. Unfortunately, the absence of such mechanisms, a systematic approach to the primary tendencies selection of innovative processes in beef raising leads to lower operational efficiency and investment attractiveness.

In the agricultural sector, innovation capital turnover and its growth cannot compete with the industry. In the first place it concerns new animal and plant varieties breeding, to create and master which needs decades. Disparities reducing between livestock development level in Ukraine and in developed countries are impossible without an innovative breakout strategy that requires maximum optimization of limited financial, investment, logistical resources.

Scientists distinguish the following fundamental innovative processes approaches in the livestock: biological, technical and technological, organizational and economic. (Nechaev, 2009) In livestock, beef raising in particular, the important 
role is played by biological methods, connected with animals feeding peculiarities, their genetic potential, genetic engineering. Technical and technological methods allow increasing efficient usage of industry's resources due to the powerand resource-saving technology, science-driven beef production. Organizational-economic methods include production rational organization, skilled labor training, and innovative management improvement, and enable different ways of innovative activities coordination.

In the market conditions for first of all it is important to reduce production costs to the world's average level, it is possible in case of qualitative improvement of chain reproductive process through innovations that can substantially change the nature of the industry, accelerate its economic growth for providing the necessary profitability and competitiveness of beef cattle. Only complex development of innovative processes directions can provide technological breakout in beef rising.

The strengthening of economic growth innovative component is impossible without a significant increase of investments' level and quality. In the developed price disparity conditions and technological backwardness of most agricultural units, it is the necessary state regulation of interrelationships, creation of contributory economic and legal conditions that motivate businesses to finance innovative projects for the growth of investment activities.
Current global trends of feed increase in price inevitably lead to production costs increase in the industry. This requires constant monitoring of ratio adequacy of product prices and production costs. That's why enterprises, providing normative conditions of technological process, require state guaranteed support of profitable production in order to prevent any further reduction in livestock.

\section{3. CONCLUSION}

Thus, the assessment of the beef cattle industry in Bukovina suggests reducing the number of cattle in all categories. The main reason for this negative trend is unprofitable beef production, which is primarily due to the low animal's productiveness, realizable price of live weight and its high cost. It's established that to solve the strategic tasks of beef rising breeding it's necessary to support the innovative activities of scientific and technological progress and innovative organizational economic reforms in agriculture.

Priority lines of innovative processes in this field are connected with the improvement of cattle's quality and species composition, feed production and feeding system, the usage of power-saving technologies, which take into account beef raising reproduction peculiarities and make it possible to improve efficiency and competitiveness of agricultural field.

\section{Works Cited}

Cherkaschenko, I. (1975). Handbook of Beef Cattle Breeding. Moscow: Kolos.

Dunin, I. (2011). Factors of dynamical meat industry development in Russia. Innovative technologies in beef cattle breeding, 13-17.

Kalynka, L. (2010). Efficiency of livestock sector in the Chernivtsi region. Innovative Economy, 79-81.

Mazurenko, O. (2012). Problems of agriculture in the context of its innovative development. Economic sciences, 248-253.

Nechaev, V. (2009). Problems of innovative development of livestock. Krasnodar: "Atri."

Petryshyn, L. (2008). Innovation in livestock. Foothill and mountain agriculture and livestock, 39-47.

Prysiazhniuk, M. (2011). Agricultural sector of Ukraine (the state and prospects of development). Kyiv: NSC IAE. 
Putsenteilo, P. (2012). Innovative development of livestock in Ukraine. Formation of strategy of scientific, technical, environmental and socio-economic development of society, 129-132.

Vyhrystiuk, M. (2006). Beef cattle breeding in Bukovina. Offer, 95-97.

Received for publication: 11.02 .2013

Revision received: $\quad 06.03 .2013$

Accepted for publication: 29.03.2013

\section{How to cite this article?}

Style - APA Sixth Edition:

Nakai, O. (2013, 07 15). Development of beef raising product manufacturing on the innovative basis.

(Z. Čekerevac, Ed.) MEST Journal, 1(2), 80-87. doi:10.12709/mest.01.01.02.07

Style - Chicago Fifteenth Edition:

Nakai, Oleksandr. "Development of beef raising product manufacturing on the innovative basis."

Edited by Zoran Čekerevac. MEST Journal (MESTE) 1, no. 2 (07 2013): 80-87.

Style - GOST Name Sort:

Nakai Oleksandr Development of beef raising product manufacturing on the innovative basis [Journal] = Development of beef raising product manufacturing // MEST Journal / ed. Čekerevac Zoran. - Belgrade : MESTE, 07 15, 2013. - 2 : Vol. 1. - pp. 80-87. - ISSN 2334-7058 (Online); ISSN 2334-7171.

Style - Harvard Anglia:

Nakai, O., 2013. Development of beef raising product manufacturing on the innovative basis. MEST Journal, 15 07, 1(2), pp. 80-87.

Style - ISO 690 Numerical Reference:

Development of beef raising product manufacturing on the innovative basis. Nakai, Oleksandr. [ed.] Zoran Čekerevac. 2, Belgrade : MESTE, 07 15, 2013, MEST Journal, Vol. 1, pp. 80-87. ISSN 23347058 (Online); ISSN 2334-7171. 